\title{
Tea and coffee consumption in relation to vitamin D and calcium levels in Saudi adolescents
}

\author{
Abdulaziz Al-Othman ${ }^{1,2}$, Sara Al-Musharaf ${ }^{3}$, Nasser M Al-Daghri ${ }^{1,4,5,11^{*}}$, Sobhy Yakout ${ }^{4}$, Khalid M Alkharfy ${ }^{1,6}$, \\ Yousef Al-Saleh ${ }^{1,7}$, Omar S Al-Attas ${ }^{1,4,5}$, Majed S Alokail ${ }^{1,4,5}$, Osama Moharram ${ }^{8}$, Shaun Sabico ${ }^{4}$, \\ Sudhesh Kumar ${ }^{9}$ and George P Chrousos ${ }^{4,10}$
}

\begin{abstract}
Background: Coffee and tea consumption was hypothesized to interact with variants of vitamin D-receptor polymorphisms, but limited evidence exists. Here we determine for the first time whether increased coffee and tea consumption affects circulating levels of 25-hydroxyvitamin D in a cohort of Saudi adolescents.

Methods: A total of 330 randomly selected Saudi adolescents were included. Anthropometrics were recorded and fasting blood samples were analyzed for routine analysis of fasting glucose, lipid levels, calcium, albumin and phosphorous. Frequency of coffee and tea intake was noted. 25-hydroxyvitamin D levels were measured using enzyme-linked immunosorbent assays.

Results: Improved lipid profiles were observed in both boys and girls, as demonstrated by increased levels of HDLcholesterol, even after controlling for age and BMI, among those consuming 9-12 cups of coffee/week. Vitamin D levels were significantly highest among those consuming 9-12 cups of tea/week in all subjects ( $p$-value 0.009) independent of age, gender, BMI, physical activity and sun exposure.

Conclusion: This study suggests a link between tea consumption and vitamin D levels in a cohort of Saudi adolescents, independent of age, BMl, gender, physical activity and sun exposure. These findings should be confirmed prospectively.
\end{abstract}

Keywords: Coffee intake, Tea intake, Vitamin D levels, Saudi adolescents

\section{Background}

Coffee is arguably the most widely consumed noncarbonated beverage around the world [1]. In Saudi Arabia, the Arabian coffee "Gahwa", is a common hot drink. It is a mainstay drink served to guests, consumed almost daily in most Saudi homes, and is served heavily in all local social occasions and gatherings. This coffee is served in traditional standard small cups (around $30 \mathrm{ml}$ each) and is usually consumed with fresh or preserved dates.

Traditionally, the beneficial effects of coffee have been attributed solely to caffeine, but increasing evidence suggests that other compounds may contribute to the health benefits of coffee consumption [2]. In fact, coffee is a

\footnotetext{
* Correspondence: aldaghri2011@gmail.com

${ }^{1}$ Prince Mutaib Chair for Biomarkers of Osteoporosis, King Saud University, Riyadh, KSA

${ }^{4}$ Biomarkers Research Program, Biochemistry Department, College of Science, King Saud University, Riyadh, Kingdom of Saudi Arabia (KSA)

Full list of author information is available at the end of the article
}

complex mixture of compounds composed of more than a thousand different chemicals, including carbohydrates, lipids, nitrogenous compounds, vitamins, minerals, alkaloids and phenolic compounds among them caffeine, cafestol, and kahweol [3].

The effects of caffeine consumption in children is limited, and most studies have focused on behavioral effects [4]. In general, caffeine doses less than $3.0 \mathrm{mg} / \mathrm{kg}$ of body weight have not resulted in any adverse effects on children in controlled clinical trials, but concerns regarding its effects on the developing nervous system have led to recommendations that daily intake should be limited to $2.5 \mathrm{mg} / \mathrm{kg}$ of body weight [5].

With regards to bone metabolism, increased coffee consumption was documented to cause a negative shift in overall calcium balance, but was not related to bone turnover in postmenopausal women with fracture osteoporosis [6]. Furthermore, caffeine was observed to

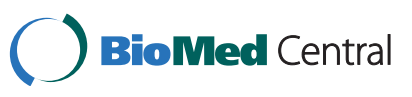

(c) 2012 Al-Othman et al.; licensee BioMed Central Ltd. This is an Open Access article distributed under the terms of the Creative Commons Attribution License (http://creativecommons.org/licenses/by/2.0), which permits unrestricted use, distribution, and reproduction in any medium, provided the original work is properly cited. 
interact with the TT genetic variant of vitamin D receptor [7]. Hannan and colleagues however reported no association between caffeine intake on bone metabolism [8]. There is scarcity of information with regards to tea consumption and vitamin D, although in terms of skeletal effect, it has been reported that excessive consumption of brewed tea can lead to skeletal fluorosis and increased bone mineral density [9]. This study aims to determine associations between the frequency of coffee and tea consumption and serum measures of vitamin D and calcium levels in a cohort of adolescent Saudis.

\section{Methods}

In this cross-sectional study, a total of 330 (155) Saudi boys and (175) girls aged 11-14 years were randomly selected from the existing Biomarkers Screening in Riyadh Program (RIYADH Cohort), a capital-wide study composed of randomly selected individuals from different Primary Health Care Centers (PHCCs) in Riyadh, KSA. The study was carried out at the Biomarkers Research Program (BRP), King Saud University, Riyadh, KSA. A selfadministered questionnaire was given to all participating subjects containing demographic and dietary information, particularly the frequency of coffee and tea intake. No distinction was made between the types of coffee (filtered, boiled, instant, pads) and between caffeinated and decaffeinated coffee. Subjects were divided into three groups based on coffee and tea consumption: Group I included those who drank 0to 4 cups of tea or coffee weekly, group II included those who consume 5-8 cups of tea or coffee per week and group III included those who consume tea or coffee 8-12 times per week. Furthermore, the questionnaire also sought information about sun exposure [frequency of exposure (e.g. no exposure, daily weekly) and physical activity [inactive, moderate, active], which were self reported.

Children with co-morbidities that needed immediate medical attention were excluded from the study. Written consent was obtained after orientation of the study protocol. Ethical approval was granted by the Ethics Committee of the College of Science Research Center, King Saud University, Riyadh, KSA.

\section{Anthropometry and blood collection}

Participating subjects were requested to return to their respective PHCCs after an overnight fast for anthropometry and blood withdrawal. Anthropometry included height (to the nearest $0.5 \mathrm{~cm}$ ), weight (to the nearest $0.1 \mathrm{~kg}$ ), utilizing a standardized measuring tape in $\mathrm{cm}$; and BMI (calculated as $\mathrm{kg} / \mathrm{m}^{2}$ ). Blood was transferred immediately to a non-heparinized tube for centrifugation. Serum was then transferred to a prelabeled plain tube, stored in ice, and delivered to the
Biomarker Research Program in King Saud University on the same day.

\section{Sample analyses}

Fasting serum samples were stored in a $-20 \mathrm{C}$ freezer until analysis. Fasting blood glucose, lipid profile, phosphorus and calcium were measured using a chemical analyzer (Konelab, Vantaa, Finland). Serum 25-OH-VitD was measured by enzyme linked immunosorbent assays (ELISA) (IDS Ltd, Boldon Colliery, Tyne \& Wear, UK) according to manufacturer's instruction. The inter- and intra-assay variabilities for 25-OH D ELISA were 5.3\% and $4.6 \%$ respectively. All sample measurements were done in BRP, a participating laboratory for DEQAS (Vitamin D External Quality Assessment Scheme) based in UK.

\section{Statistical analysis}

Data was analyzed using the Statistical Package for the Social Sciences (SPSS for Windows version 16.5). Data are expressed as mean \pm standard deviation for normally distributed parameters. Group comparisons were done using analysis of covariance (ANCOVA), adjusted for age and BMI. P-value less than 0.05 was deemed significant.

\section{Results}

Comparisons between subjects based on coffee consumption are presented in Table 1 . In both males and females, those consuming the most coffee cups per week were significantly younger with lower BMI, lean and soft body mass as compared to those who were drinking coffee less. In males, LDL- and HDL-cholesterol levels were highest among those consuming coffee 9-12 times week ( $\mathrm{p}$-values 0.022 and 0.0008 respectively) and although the same trend were observed in females, only HDL-cholesterol was significant. Circulating 25-hydroxyvitamin D levels were significantly elevated among girls consuming coffee 9-12 times per week, even after adjusting for age and BMI.

Comparisons between subjects based on tea consumption are presented in Table 2. While most of the variables were comparable with one another in both genders, vitamin D levels were observed to be highest among both genders consuming the most tea per week (9-12 times/week) and these significance was independent from age and BMI. Figure 1 shows the effect of increased tea intake $(1 \mathrm{~A})$ in the vitamin D status of subjects independent of age, gender, BMI, sun exposure and physical activity. Subjects who consumed 0-4 times of tea per week had significantly lower $25(\mathrm{OH}) \mathrm{D}$ levels as compared to those consuming 8-12 times/week. No significant difference in $25(\mathrm{OH}) \mathrm{D}$ was found when compared to coffee intake (B). 
Table 1 Comparison of male and female subjects based on coffee intake

\begin{tabular}{|c|c|c|c|c|c|c|c|c|}
\hline \multirow{4}{*}{ Parameters } & \multicolumn{4}{|c|}{ Males } & \multicolumn{4}{|c|}{ Females } \\
\hline & \multirow{2}{*}{$\frac{\text { Group } 1}{0-4}$} & \multirow{2}{*}{$\frac{\text { Group } 2}{5-8}$} & \multirow{2}{*}{$\frac{\text { Group } 3}{9-12}$} & \multirow[t]{3}{*}{ p-value } & \multirow{2}{*}{$\frac{\text { Group } 1}{0-4}$} & \multirow{2}{*}{$\frac{\text { Group } 2}{5-8}$} & \multirow{2}{*}{$\frac{\text { Group } 3}{9-12}$} & \multirow[t]{3}{*}{ p-value } \\
\hline & & & & & & & & \\
\hline & times/week & times/week & times/week & & times/week & times/week & times/week & \\
\hline N & 60 & 16 & 75 & & 83 & 22 & 70 & \\
\hline Age(years) & $13.2 \pm 3.1$ & $13.4 \pm 2.5$ & $11.6 \pm 3.4$ & 0.009 & $13.5 \pm 3.2$ & $12.0 \pm 3.6$ & $12.3 \pm 3.3$ & 0.035 \\
\hline BMI $\left(\mathrm{kg} / \mathrm{m}^{2}\right)$ & $22.6 \pm 8.2$ & $22.9 \pm 6.8$ & $19.5 \pm 5.1$ & 0.020 & $23.1 \pm 7.1$ & $18.6 \pm 4.0$ & $21.3 \pm 6.4$ & 0.016 \\
\hline Sun Exposure (\%) (Daily/weekly) & $60 / 25$ & $31 / 50$ & $44 / 36$ & 0.16 & $20.7 / 26.5$ & $22.7 / 50.0$ & $28.5 / 50.0$ & 0.001 \\
\hline Physical Activity (\%)(moderate/Active) & $20 / 46.6$ & $25 / 62.5$ & 10.6/64.0 & 0.14 & $13.2 / 65.0$ & $22.7 / 68.1$ & $15.7 / 67.1$ & 0.39 \\
\hline Waist (cm) & $67.4 \pm 30.0$ & $72.3 \pm 14.6$ & $63.7 \pm 15.1$ & 0.343 & $65.5 \pm 23.0$ & $62.4 \pm 10.0$ & $68.2 \pm 12.4$ & 0.413 \\
\hline Hips (cm) & $78.3 \pm 30.6$ & $89.3 \pm 16.4$ & $77.6 \pm 20.1$ & 0.246 & $82.2 \pm 24.4$ & $79.4 \pm 13.7$ & $86.4 \pm 15.4$ & 0.299 \\
\hline LBM (kg) & $40.8 \pm 15.2$ & $34.2 \pm 10.0$ & $32.1 \pm 12.8$ & 0.010 & $34.1 \pm 9.2$ & $27.4 \pm 8.9$ & $31.3 \pm 8.9$ & 0.015 \\
\hline SLM (kg) & $36.2 \pm 14.3$ & $31.8 \pm 9.5$ & $28.9 \pm 12.3$ & 0.011 & $32.0 \pm 9.4$ & $25.3 \pm 8.4$ & $28.8 \pm 8.4$ & 0.010 \\
\hline Glucose $\left(\mathrm{mmol} / \mathrm{l}^{\dagger}\right.$ & $5.2 \pm 0.77$ & $5.4 \pm 1.0$ & $5.3 \pm 0.60$ & 0.193 & $5.0 \pm 0.85$ & $5.0 \pm 0.65$ & $5.1 \pm 0.52$ & 0.299 \\
\hline Triglycerides $(\mathrm{mmol} / \mathrm{l})^{+}$ & $0.94 \pm 0.05$ & $1.1 \pm 0.08$ & $0.80 \pm 0.04$ & 0.111 & $0.94 \pm 0.08$ & $0.78 \pm 0.02$ & $0.86 \pm 0.03$ & 0.243 \\
\hline $\mathrm{HDL}(\mathrm{mmol} / \mathrm{l})^{\dagger}$ & $0.89 \pm 0.35$ & $1.05 \pm 0.20$ & $1.1 \pm 0.26^{*}$ & 0.022 & $1.02 \pm 0.31$ & $1.1 \pm 0.19$ & $1.2 \pm 0.25^{*}$ & 0.034 \\
\hline $\operatorname{LDL}(\mathrm{mmol} / \mathrm{l})^{\dagger}$ & $2.9 \pm 0.68$ & $2.8 \pm 0.58$ & $2.5 \pm 0.57^{*}$ & 0.008 & $2.9 \pm 0.66$ & $2.6 \pm 0.57$ & $2.7 \pm 0.60$ & 0.088 \\
\hline T. Cholesterol $\left(\mathrm{mmol} / \mathrm{I}^{\dagger}\right.$ & $4.3 \pm 1.5$ & $4.2 \pm 0.65$ & $3.8 \pm 0.62^{*}$ & 0.043 & $4.3 \pm 0.65$ & $3.9 \pm 0.56$ & $4.1 \pm 0.66$ & 0.061 \\
\hline Serum Ca $\left(\mathrm{mmol} / \mathrm{l}^{\dagger}\right.$ & $2.5 \pm 0.26$ & $2.5 \pm 0.16$ & $2.6 \pm 0.16^{*}$ & 0.008 & $2.4 \pm 0.19$ & $2.6 \pm 0.12$ & $2.5 \pm 0.20$ & 0.100 \\
\hline Corrected $\mathrm{Ca}(\mathrm{mmol} /)^{\dagger}$ & $2.6 \pm 0.32$ & $2.6 \pm 0.39$ & $2.6 \pm 0.24$ & 0.582 & $2.4 \pm 0.38$ & $2.5 \pm 0.10$ & $2.5 \pm 0.20$ & 0.931 \\
\hline Albumin $(\mathrm{gm} / \mathrm{L})^{\dagger}$ & $45.5 \pm 4.5$ & $45.8 \pm 4.0$ & $45.1 \pm 3.2$ & 0.891 & $44.8 \pm 3.4$ & $46.5 \pm 2.7$ & $44.3 \pm 3.6$ & 0.050 \\
\hline Serum Phosphorus ${ }^{\dagger}$ & $1.6 \pm 0.63$ & $1.5 \pm 0.30$ & $1.6 \pm 0.38$ & 0.891 & $1.4 \pm 0.9$ & $1.4 \pm 0.24$ & $1.3 \pm 0.30$ & 0.481 \\
\hline Vitamin D $(\mathrm{nmol} / \mathrm{l})^{\dagger}$ & $24.0 \pm 1.5$ & $20.7 \pm 1.3$ & $25.4 \pm 1.6$ & 0.212 & $16.7 \pm 1.6$ & $19.4 \pm 1.5$ & $20.5 \pm 1.5^{*}$ & 0.020 \\
\hline
\end{tabular}

Data represented by Mean \pm standard deviation;

' $\mathrm{t}$ 'Represents Analysis of Co variance (ANCOVA) is done across the coffee drinkers, Adjusted for age and BMI.

\section{Discussion}

To the best of our knowledge, there is no recorded study on the association of caffeine intake with circulating levels of 25-hydroxyvitamin D. Current evidence however relate caffeine intake to calcium metabolism [10-12]. It has been demonstrated that caffeine negatively influences calcium balance by reducing renal reabsorption of calcium, and possibly by reducing intestinal calcium absorption efficiency. High caffeine intake may involve considerable renal and intestinal calcium losses [13]. Results of previous epidemiological studies have suggested a relationship between high caffeine consumption and low bone mineral density (BMD) and osteoporotic fractures, which however may be offset by a high calcium intake $[14,15]$. Caffeine intake also reduces inositol levels in the blood. Inositol is a regulating factor in calcium metabolism [13], and can modestly increase calcium excretion and reduce absorption (Barrett-Connor et al., 1994). Caffeine intake $>300 \mathrm{mg} / \mathrm{d}(\approx 514 \mathrm{~g}$, or $18 \mathrm{oz}$, brewed coffee) accelerate bone loss at the spine in elderly postmenopausal women [7]. Furthermore, women who harbor the TT genetic variant of $V D R$ appear to be at a greater risk for this deleterious effect of caffeine on bone [7]. The polymorphisms in the VDR gene correlate with BMD, bone turnover and bone loss $[16,17]$. In our study, serum vitamin $\mathrm{D}$ level increases as coffee and tea consumption increases. Increased caffeine dose decreases VDR protein expression and alkaline phosphatase enzyme activity, a marker of osteoblast differentiation in osteoblast cells [18]. Caffeine is also metabolized in the liver via the cytochrome P450 oxidase enzyme system [19,20]. About a dozen metabolites can be recovered in the urine of regular coffee consumers [19,21]. Methylxanthine, theophylline and caffeine were found to inhibit the conversion of 25 hydroxyvitamin D3, to 1,25 dihydroxyvitamin D3 in isolated renal tubules in vitamin $\mathrm{D}$ deficient chicks, which led to increased vitamin D circulating levels [22].

The role of caffeine as a risk factor for bone loss is controversial. Moderate coffee consumption has no effect on bone health [13]. However, low calcium intake is clearly linked to skeletal fragility, and it is likely that a high caffeine intake is often a marker for low calcium intake [11]. The negative effect of caffeine on calcium absorption is small enough to be fully offset by as little as 1-2 tablespoons of milk. All of these observations implicating caffeine-containing beverages as a risk factor for 
Table 2 Comparison of male and female subjects based on tea intake

\begin{tabular}{|c|c|c|c|c|c|c|c|c|}
\hline \multirow{5}{*}{ Parameters } & \multicolumn{8}{|c|}{ Tea Intake } \\
\hline & \multicolumn{4}{|c|}{ Male } & \multicolumn{4}{|c|}{ Female } \\
\hline & \multirow{2}{*}{$\frac{\text { Group } 1}{0-4}$} & \multirow{2}{*}{$\frac{\text { Group } 2}{5-8}$} & \multirow{2}{*}{$\frac{\text { Group } 3}{9-12}$} & \multirow[t]{3}{*}{$\mathrm{p}$-value } & \multirow{2}{*}{$\frac{\text { Group } 1}{0-4}$} & \multirow{2}{*}{$\frac{\text { Group } 2}{5-8}$} & \multirow{2}{*}{$\frac{\text { Group } 3}{9-12}$} & \multirow[t]{3}{*}{ p-value } \\
\hline & & & & & & & & \\
\hline & times/week & $\overline{\text { times/week }}$ & times/week & & times/week & $\overline{\text { times/week }}$ & times/week & \\
\hline N & 96 & 23 & 36 & & 105 & 17 & 53 & \\
\hline Age(years) & $12.7 \pm 3.3$ & $12.5 \pm 3.2$ & $11.7 \pm 3.5$ & 0.274 & $13.0 \pm 3.4$ & $12.5 \pm 3.4$ & $12.7 \pm 3.2$ & 0.808 \\
\hline BMI $\left(\mathrm{kg} / \mathrm{m}^{2}\right)$ & $21.1 \pm 6.6$ & $23.7 \pm 8.0$ & $19.9 \pm 6.7$ & 0.177 & $22.1 \pm 6.2$ & $21.2 \pm 3.6$ & $21.5 \pm 8.0$ & 0.763 \\
\hline Sun Exposure (\%) (Daily/weekly) & $54 / 29.1$ & $30.4 / 30.4$ & $38.8 / 47.2$ & 0.17 & $19.0 / 34.2$ & $23.5 / 47.0$ & $22.6 / 41.5$ & 0.06 \\
\hline $\begin{array}{l}\text { Physical Activity } \\
(\%)(\text { moderate/Active) }\end{array}$ & $21.0 / 51.0$ & $13.0 / 60.8$ & $11.0 / 63.8$ & 0.04 & $16.1 / 64.7$ & $17.6 / 76.4$ & $15.1 / 67.9$ & 0.91 \\
\hline Waist (cm) & $65.5 \pm 23.6$ & $69.2 \pm 24.6$ & $65.7 \pm 17.6$ & 0.816 & $64.2 \pm 18.0$ & $67.8 \pm 8.8$ & $69.9 \pm 18.4$ & 0.177 \\
\hline Hips (cm) & $77.4 \pm 25.4$ & $83.8 \pm 25.9$ & $80.7 \pm 22.6$ & 0.555 & $81.0 \pm 22.0$ & $86.8 \pm 8.2$ & $87.7 \pm 18.1$ & 0.138 \\
\hline LBM (kg) & $35.7 \pm 13.6$ & $36.7 \pm 13.8$ & $33.5 \pm 14.8$ & 0.672 & $32.4 \pm 9.7$ & $32.2 \pm 6.2$ & $31.6 \pm 9.3$ & 0.913 \\
\hline SLM (kg) & $32.5 \pm 12.9$ & $34.2 \pm 13.1$ & $29.9 \pm 14.1$ & 0.510 & $30.4 \pm 9.8$ & $29.8 \pm 5.8$ & $29.1 \pm 8.9$ & 0.738 \\
\hline Glucose $(\mathrm{mmol} / \mathrm{l})^{\dagger}$ & $5.2 \pm 0.81$ & $5.3 \pm 0.38$ & $5.3 \pm 0.69$ & 0.904 & $4.9 \pm 0.78$ & $5.0 \pm 0.72$ & $5.2 \pm 0.51$ & 0.160 \\
\hline $\mathrm{TG}(\mathrm{mmol} / \mathrm{l})^{\dagger}$ & $0.90 \pm 0.05$ & $1.1 \pm 0.07$ & $0.78 \pm 0.04$ & 0.062 & $0.87 \pm 0.04$ & $0.99 \pm 0.12$ & $0.90 \pm 0.04$ & 0.600 \\
\hline $\mathrm{HDL}\left(\mathrm{mmol} / \mathrm{l}^{\dagger}\right.$ & $1.0 \pm 0.34$ & $1.0 \pm 0.22$ & $1.01 \pm 0.23$ & 0.959 & $1.0 \pm 0.29$ & $1.2 \pm 0.23^{*}$ & $1.1 \pm 0.24^{*}$ & 0.003 \\
\hline $\mathrm{LDL}(\mathrm{mmol} /)^{\dagger}$ & $2.8 \pm 0.61$ & $2.6 \pm 0.63$ & $2.4 \pm 0.65^{*}$ & 0.042 & $2.9 \pm 0.64$ & $2.7 \pm 0.37$ & $2.7 \pm 0.68$ & 0.274 \\
\hline Total Cholesterol $(\mathrm{mmol} /)^{\dagger}$ & $4.2 \pm 1.2$ & $3.9 \pm 0.67$ & $3.8 \pm 0.70$ & 0.111 & $4.2 \pm 0.66$ & $4.1 \pm 0.40$ & $4.0 \pm 0.71$ & 0.667 \\
\hline Serum Ca $(\mathrm{mmol} /)^{\dagger}$ & $2.5 \pm 0.24$ & $2.6 \pm 0.21$ & $2.6 \pm 0.20$ & 0.322 & $2.5 \pm 0.20$ & $2.4 \pm 0.18$ & $2.6 \pm 0.23$ & 0.184 \\
\hline Corrected Ca $(\mathrm{mmol} / \mathrm{l})^{\dagger}$ & $2.6 \pm 0.34$ & $2.4 \pm 0.20$ & $2.5 \pm 0.23$ & 0.132 & $2.5 \pm 0.33$ & $2.5 \pm 0.21$ & $2.5 \pm 0.17$ & 0.972 \\
\hline Albumin $(\mathrm{gm} / \mathrm{L})^{\dagger}$ & $45.7 \pm 3.9$ & $45.7 \pm 4.4$ & $44.6 \pm 3.2$ & 0.427 & $44.8 \pm 3.9$ & $44.6 \pm 2.7$ & $44.6 \pm 2.9$ & 0.936 \\
\hline Serum Phosphorus ${ }^{\dagger}$ & $1.6 \pm 0.56$ & $1.5 \pm 0.31$ & $1.5 \pm 0.25$ & 0.741 & $1.4 \pm 0.9$ & $1.3 \pm 0.2$ & $1.4 \pm 0.30$ & 0.802 \\
\hline Vitamin D $(\mathrm{nmol} /)^{\dagger}$ & $22.5 \pm 1.5$ & $23.5 \pm 1.4$ & $30.0 \pm 1.5^{*}$ & 0.003 & $17.4 \pm 1.6$ & $17.2 \pm 1.4$ & $21.2 \pm 1.5^{*}$ & 0.031 \\
\hline
\end{tabular}

Data represented by Mean \pm standard deviation;

Analysis of Variance (ANOVA) is done across different tea drinkers.

‘*' represents group is significantly from the group 1 .

osteoporosis have been made in populations consuming substantially less than optimal calcium intakes [11].

Another factor that may contribute to higher vitamin $\mathrm{D}$ in the heavy drinkers is the weight reducing effect of coffee. In our study BMI mean value was significantly decreased in heavy drinkers when compared to low and moderate drinkers (mean of BMI $=20 \pm 5.8 \mathrm{~kg} / \mathrm{m} 2$, $\mathrm{P}<0.05)$. Both sexes showed a decrease in BMI (appendix). In a study done by Jorde et al. (2001), both gender's serum calcium showed a positive association with body mass index (BMI) and coffee consumption that persisted after correcting for other variables in a multiple regression model $(\mathrm{P}<0.05)$ [23].

Coffee intake should reduce BMI because coffee consumption decreases the amount of fat tissue by elevating thermogenesis [24-26] and stimulating the sympathoadrenal system [27]. Aside from caffeine's ability to increase fat oxidation and lipolysis [28-30], there is a weak but significant positive association with BMI for coffee intake in both sexes [30]. Coffee may reduce body weight through lipolysis stimulation [27]. Fat loss from adipose tissue is hypothesized to be accompanied by vitamin $\mathrm{D}$ withdrawal from its fat store leading to elevated serum vitamin D levels. Studies on weight reduction show that serum $25(\mathrm{OH}) \mathrm{D}$ levels rise when obese individuals lose body fat [31-33].

There is consistent epidemiological evidence that consumption of these hot beverages is associated with a reduced risk of diabetes mellitus type 2 (DMT2) and coronary heart disease [34-36]. It has been hypothesized that the protective effect of coffee and tea consumption on DMT2 risk is mediated by a reduction in obesity [37]. This hypothesis is supported by a handful of clinical intervention studies which report that the frequency of coffee or tea consumption is related to weight loss and change in body fat distribution $[37,38]$.

The study has limitations. Comprehensive data on outdoor physical activity and diet were lacking, and these can be considered major confounders that affect circulating vitamin D levels. The type of coffee and tea were also not taken into consideration. Nevertheless, the number of subjects involved increases the reliability of 

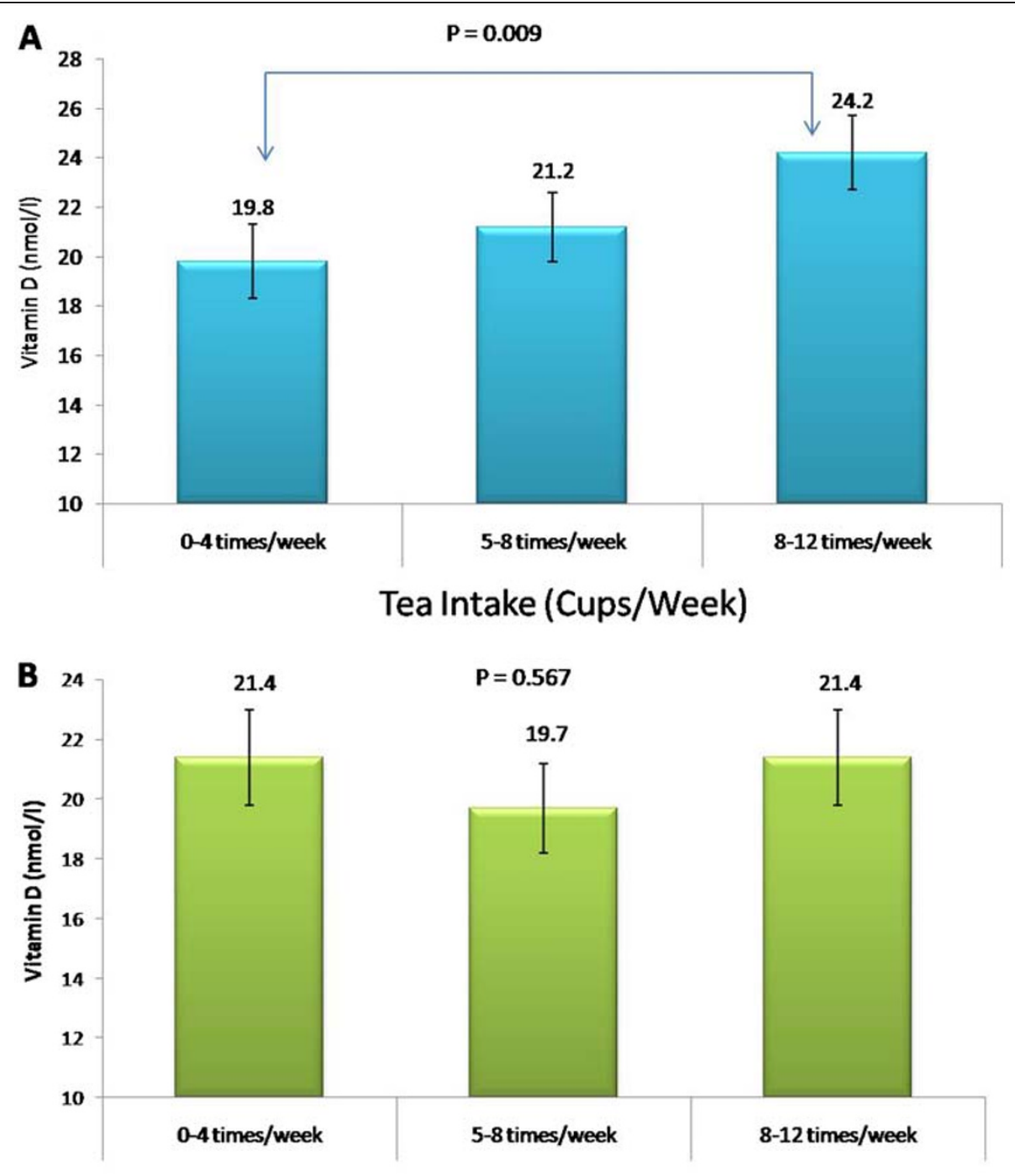

\section{Coffee Intake (Cups/Week)}

Figure 1 Levels of 25(OH)D according to tea (A) and coffee (B) consumption. Comparisons were adjusted for age, BMl, gender, physical activity and sun exposure. Significance set at $\boldsymbol{p}<0.05$.

our results, which shows for the first time a dosedependent relationship between circulating vitamin $\mathrm{D}$ levels in relation to coffee and tea consumption among Saudi adolescents, even after adjustment for physical activity, sun exposure, gender, age and BMI.

In summary, the study suggests that increased coffee and tea consumption elevates circulating vitamin D levels among Saudi Arab adolescents independent of physical activity, sun exposure, age, gender and BMI. Further studies are needed to confirm these findings as assessment of the health risks and benefits of coffee and tea consumption requires reliable data that can accurately for studying relationships between coffee and tea consumption and health-related endpoints.

\section{Competing interests}

The authors declare that they have no competing interests

\section{Authors' contributions}

AA, SA and NMA conceived and carried out the study. KMA, YA, OSA and MSA participated in the design, subject recruitments and data collection. OM and SY carried out sample analysis. SA, SS, SK and GPC performed statistical analysis and drafted the final version of the manuscript. All authors approved and read the final manuscript.

\section{Acknowledgments}

The authors wish to thank Mr. Benjamin Vinodson for the statistical analyses of the data.

\section{Author details}

${ }^{1}$ Prince Mutaib Chair for Biomarkers of Osteoporosis, King Saud University, Riyadh, KSA. ${ }^{2}$ College of Applied Medical Sciences, King Saud University, Riyadh, KSA. ${ }^{3}$ College of Science, King Saud University Women's Section, 
Riyadh, KSA. ${ }^{4}$ Biomarkers Research Program, Biochemistry Department, College of Science, King Saud University, Riyadh, Kingdom of Saudi Arabia (KSA). ${ }^{5}$ Center of Excellence in Biotechnology Research, King Saud University, Riyadh, KSA. ${ }^{6}$ Clinical Pharmacy Department, College of Pharmacy, King Saud University, Riyadh, KSA. ${ }^{7}$ College of Medicine, King Saud University of Health Sciences, Riyadh, KSA. ${ }^{8}$ King Abdulaziz University Hospital, King Saud University, Riyadh, KSA. ${ }^{9}$ Clinical Sciences Research Institute, Diabetes and Metabolism Unit, Warwick University, Coventry CV47AL, UK. ${ }^{10}$ First Department of Pediatrics, Athens University Medical School, Athens 11527, Greece. ${ }^{11}$ Prince Mutaib Bin Abdullah Chair for Osteoporosis, Biochemistry Department, College of Science, King Saud University, PO Box, 2455, Riyadh 11451, Kingdom of Saudi Arabia.

Received: 3 January 2012 Accepted: 11 August 2012

Published: 20 August 2012

\section{References}

1. Food and Agricultural Organization: Food balance sheets. http://www.fao. org.

2. Butt MS, Sultan MT: Coffee and its consumption: Benefits and risks. Crit Rev Food Sci Nutr 2011, 51:363-373.

3. Spiller MA: The chemical components of coffee. In Caffeine. Boca Raton: CRC Press; 1998:97-161.

4. Castellanos FX, Rapoport JL: Effects of caffeine on development and behavior in infancy and childhood: a review of the published literature. Food Chem Toxicol 2002, 40:1235-1242.

5. HealthCanada: Fact Sheet Caffeine and Your Health.2003. http://www.hc-sc. gc.ca/foodaliment/dg/ecaffeine.html.

6. Hasling C, Sondergaard K, Charles P, Mosekilde L: Calcium metabolism in postmenopausal osteoporotic women is determined by dietary calcium and coffee intake. J Nutr 1992, 122:1119-1126.

7. Rapuri PB, Gallagher JC, Kinyamu HK, Ryschon KL: Caffeine intake increases the rate of bone loss in elderly women and interacts with vitamin $D$ receptor genotypes. Am J Clin Nutr 2001, 74:694-700.

8. Hannan MT, Felson DT, Dawson-Hughes B, Tucker TL, Cupples LA, Wilson PW, Kiel DP: Risk factors for longitudinal bone loss in elderly men and women: the Framingham Osteoporosis Study. J Bone Miner Res 2000, 15:710-720

9. Izuora K, Twombly JG, Whitford GM, Demertzis J, Pacifici R, Whyte MP: Skeletal fluorosis from brewed tea. J Clin Endocrinol Metab 2011, 96:23182324.

10. Heaney RP: Bone mass, nutrition, and other lifestyle factors. Nutr Rev 1996, 54:S3-10.

11. Heaney RP: Effects of caffeine on bone and the calcium economy. Food Chem Toxicol 2002, 40:1263-1270.

12. Heaney RP, Recker RR: Effects of nitrogen, phosphorus, and caffeine on calcium balance in women. J Lab Clin Med 1982, 99:46-55.

13. Massey LK, Whitling SJ: Caffeine, urinary calcium, calcium metabolism and bone. J Nutr 1993, 123:1611-1614.

14. Kreiger N, Gross A, Hunter G: Dietary factors and fracture in postmenopausal women: a case-control study. Int J Epidemiol 1992, 21:953-958.

15. Huopio J, Kroger H, Honkanen R, Saarikoski S, Alhava E: Risk factors for perimenopausal fractures: a prospective study. Osteoporos Int 2000, 11:219-227.

16. Gong G, Stern HS, Cheng SC, Fong N, Mordeson J, Deng HW, Recker RR: The association of bone mineral density with vitamin $D$ receptor gene polymorphisms. Osteoporos Int 1999, 9:55-84.

17. Woods RJ, Fleet JC: The genetics of osteoporosis: vitamin $D$ receptor polymorphisms. Annu Rev Nutr 1998, 18:233-258.

18. Rapuri PB, Gallagher JC, Nawaz Z: Caffeine decreases vitamin D receptor protein expression and 1,25(OH)2D3 stimulated alkaline phosphatase activity in human osteoblast cells. J Steroid Biochem Mol Biol 2007, 103:368-371.

19. Barone JJ, Roberts HR: Caffeine consumption. Food Chem Toxicol 1996, 34:119-129.

20. Gates S, Miners JO: Cytochrome P450 isoform selectivity in human hepatic theobromine metabolism. Br J Clin Pharmacol 1999, 47:299-305.

21. Ullrich D, Compagnone D, Munch B, Brandes A, Hille H, Bircher J: Urinary caffeine metabolites in man. Age-dependent changes and pattern in various clinical situations. Eur J Clin Pharmacol 1992, 43:167-172.
22. Taft JL, French M, Danks JA, Larkins RG: Opposing actions of methylxanthines and dibutyryl cyclic AMP on 1,25 dihydroxyvitamin D3 production and calcium fluxes in isolated chick renal tubules. Biochem Biphys Res Commun 1984, 121:355-363.

23. Jorde R, Sundsfjord J, Bonaa KH: Determinants of serum calcium in men and women. The Tromso Study. Eur J Epidemiol 2001, 17:1117-1123.

24. Tagliabue A, Terracina D, Cena H, Turconi G, Lanzola E, Montomolli C: Coffee induced thermogenesis and skin temperature. Int J Obes Relat Metab Disord 1994, 18:537-541.

25. Dulloo AG, Geissler CA, Horton T, Collins A, Miller DS: Normal caffeine consumption: influence on thermogenesis and daily energy expenditure in lean and postobese human volunteers. Am J Clin Nutr 1989, 49:44-50.

26. Graham TE: Caffeine and exercise: metabolism, endurance and performance. Sports Med 2001, 31:785-807.

27. Astrup A: Thermogenic drugs as a strategy for treatment of obesity. Endocrine 2000, 13:207-212.

28. Ryu S, Choi SK, Joung SS, Suh H, Cha YS, Lee S, Lim K: Caffeine and lipolytic food component increases endurance performance in rats and athletes. J Nutr Sci Vitaminol 2001, 47:139-146.

29. Keijzers GB, De Galan BE, Tack CJ, Smits P: Caffeine can decrease insulin sensitivity in humans. Diabetes Care 2002, 25:364-369.

30. Kamycheva $E$, Joakimsen RM, Jorde R: Intakes of calcium and vitmin D predict body mass index in the population of Northern Norway. I Nutr 2003, 133:102-106.

31. Riedt CS, Cifuentes M, Stahl T, Chowdhury HA, Schlussel Y, Shapses SA: Overweight postmenopausal women lose bone with moderate weight reduction and $1 \mathrm{~g} /$ day calcium intake. J Bone Miner Res 2005, 20:455-463.

32. Tzotas T, Papadopoulou FG, Tsiomaoos K, Karras S, Gastaris K, Perros P, Krassas GE: Rising serum 25-hydroxy-vitamin $D$ levels after weight loss in obese women correlate with improvement in insulin resistance. J Clin Endocrinol Metab 2010, 95:4251-4257.

33. Zittermann A, Frisch S, Berthold HK, Gotting C, Kuhn J, Kleesiek K, Stehle P, Koertke $H$, Koerfer R: Vitamin D supplementation enhances the beneficial effects of weight loss on cardiovascular disease risk markers. Am J Clin Nutr 2009, 89:1321-1327.

34. Higdon JV, Frei B: Coffee and health: a review of recent human research. Crit Rev Food Sci Nutr 2006, 46:101-123.

35. Schneider C, Serge T: Green tea: potential health benefits. Am Fam Physician 2009, 79:591-594.

36. Greenberg JA, Axen KV, Schnoll R, Boozer CN: Coffee, tea and diabetes: the role of weight loss and caffeine. Int J Obes (Lond) 2005, 29:1121-1129.

37. He RR, Chen L, Lin BH, Matsui Y, Yao XS, Kurihara H: Beneficial effects of oolong tea consumption on diet-induced overweight and obese subjects. Chin I Integr Med 2009, 15:34-41.

38. Thom $\mathrm{E}$ : The effect of chlorogenic acid enriched coffee on glucose absorption in healthy volunteers and its effect on body mass when used long-term in overweight and obese people. J Int Med Res 2007, 35:900-908.

doi:10.1186/1475-2891-11-56

Cite this article as: Al-Othman et al:: Tea and coffee consumption in relation to vitamin D and calcium levels in Saudi adolescents. Nutrition Journal 2012 11:56.

\section{Submit your next manuscript to BioMed Central and take full advantage of:}

- Convenient online submission

- Thorough peer review

- No space constraints or color figure charges

- Immediate publication on acceptance

- Inclusion in PubMed, CAS, Scopus and Google Scholar

- Research which is freely available for redistribution 